\title{
DNA loop organization in glioblastoma T98G cells at their different functional states
}

\author{
K. S. Afanasieva ${ }^{1}$, A. Y. Semenova ${ }^{1}$, L. L. Lukash ${ }^{2}$, A. V. Sivolob ${ }^{1}$ \\ ${ }^{1}$ ESC "Institute of Biology and Medicine", Taras Shevchenko National University of Kyiv \\ 64/13, Volodymyrska Str., Kyiv, Ukraine, 01601 \\ ${ }^{2}$ Institute of Molecular Biology and Genetics, NAS of Ukraine \\ 150, Akademika Zabolotnoho Str., Kyiv, Ukraine, 03143 \\ aphon@ukr.net
}

\begin{abstract}
The loop domain organization of chromatin, which plays an important role in transcription regulation, may depend on the cell functional state. The aim of this work was to investigate DNA loop reorganization upon functional transitions in the glioblastoma T98G cells. Methods. Single cell gel electrophoresis (a comet assay) was used to analyze the kinetics of the DNA loop migration from the nucleoids obtained from the lysed cells. Results. The cells arrested in the G1 phase of the cell cycle were characterized by a relatively low amount of DNA in the comet tails due to a low content of DNA in the loops which may be resolved by the comet assay (up to $\sim 300 \mathrm{~kb}$ ). After cell reactivation, the contour length of the loops essentially increased in parallel with a decrease in the linear loop density along the genome. Conclusions. An increase in the loop size and a respective decrease in the loop density may be a general feature of activated cells as we earlier observed similar effects upon activation of human lymphocytes.
\end{abstract}

Ke y w o r d s: DNA loops, T98G cell line, comet assay, cell functional state.

\section{Introduction}

Loop domains are known to be the key elements of a higher order chromatin structure [1-5]. The loops govern gene regulation and other functional processes in chromatin, and thus the loop organization is thought to vary depending on cell functional states $[6,7]$. Despite the comprehensive understanding of general principles of the chromatin loop forma- tion $[5,8-12]$ the reorganization of the loops upon functional transitions remains far from being studied in details.

Single-cell gel electrophoresis (the comet assay) is a well-known technique which may be applied to investigate the properties of nucleoids obtained after a cell lysis. The assay starts from the cells embedded in a thin layer of agarose on a microscope slide and then lysed. In the electric field the nucleoid DNA

C 2018 K. S. Afanasieva et al.; Published by the Institute of Molecular Biology and Genetics, NAS of Ukraine on behalf of Biopolymers and Cell. This is an Open Access article distributed under the terms of the Creative Commons Attribution License (http://creativecommons.org/licenses/by/4.0/), which permits unrestricted reuse, distribution, and reproduction in any medium, provided the original work is properly cited 
migrates towards the anode forming an electrophoretic track, which resembles a comet tail and can be visualized by fluorescent microscopy $[13,14]$.

In our previous works [15-21], measuring the kinetics of DNA exit during electrophoresis, we have shown that the nucleoid structure reflects some important features of the loop organization in vivo. Moreover, we have argued that some large-scale features of the loop domain organization (and re-organization) are preserved in nucleoids after cell lysis and hence may be detected due to a relatively simple technique, the comet assay $[20,21]$.

Most of our previous experiments were done using intact human lymphocytes. However, in our recent work [20] we have shown that the reorganization of DNA loops occurs upon the lymphocyte activation by interleukin 2, and that the loops in glioblastoma T98G cells are organized differently with respect to lymphocytes. In this article we studied these cancer cells in more details.

The T98G cell line originates from the T98 line derived from a human glioblastoma multiform tumor [22, 23]. Like many other cancer cells, the T98G cells may be cultivated in suspension. But, in contrast to most of cancer cell lines, the T98G cells can be arrested at G1 phase of the cell cycle when serum is absent in the medium $[22,23]$. At the same time, after serum addition, the cells may be reactivated to proliferation [22]. We have used these features to investigate a possible reorganization of DNA loops upon functional transitions in the T98G cells. Our results show that, indeed, the loop organization varies in different functional states of cells.

\section{Materials and Methods}

Sample preparation. The $\mathrm{T} 98 \mathrm{G}$ cells were cultivated at $37^{\circ} \mathrm{C}$ in Dulbecco's medium, which contained $10 \%$ fetal bovine serum and antibiotics. In order to synchronise the culture and stimulate its arrest in G1 phase, the cells were put in the same medium without serum and incubated for 48 hours. For reactivation to proliferation the cells were precipitated by centrifugation, put in Dulbecco's medium with $10 \%$ fetal bovine serum and cultivated for 8 hours. The cells (either G1-arrested or reactivated) were collected by centrifugation and washed twice with PBS buffer $(137 \mathrm{MM} \mathrm{NaCl}$, $2.7 \mathrm{MM} \mathrm{KCl}, 10 \mathrm{MM} \mathrm{Na}_{2} \mathrm{HPO}_{4}, 2 \mathrm{MM} \mathrm{KH}_{2} \mathrm{PO}_{4}$, $\mathrm{pH}$ 7.4). In some cases nuclei were isolated from the cells as described [19].

The comet assay was performed as described earlier [15-20]. Briefly, the cells (or nuclei) were embedded in the $0.67 \%$ agarose gel on the surface of a microscope slide. Slides were treated with ice-cold lysis solution $(2.5 \mathrm{M}$ $\mathrm{NaCl}, 100 \mathrm{mM}$ EDTA, $10 \mathrm{mM}$ Tris- $\mathrm{HCl}$ (pH 8.0), 1 \% Triton X-100 (Ferak, Germany)) for several hours. Then the slides were washed twice by TBE buffer $(89 \mathrm{MM}$ Tris-borat, $2 \mathrm{MM}$ EDTA, pH 7.5) and electrophoresed in the same buffer. In some cases chloroquine (Sigma, USA) was added to the electrophoresis buffer. Several slides, simultaneously prepared in the same way, were placed into the electrophoresis tank, and then were taken out every 10 minutes of electrophoresis. After electrophoresis the slides were stained with DAPI and immediately analyzed with a fluorescent microscope. In total 100-150 randomly chosen nucleoids on each slide were examined using image analysis software CometScore (TriTec, USA) to determine the relative amount 
of DNA in the tails and the tail length. The relative amount of DNA in the tail was determined as the ratio of the tail fluorescence intensity to the total intensity of the comet. The tail length was defined as the distance from the center of mass of the comet head to [the] distal end of the tail. Taking the contour length of the loop to be roughly two times longer than the extended loop, the tail length was multiplied by two and divided by $0.34 \mathrm{~nm}$ (the distance between the adjacent base pairs) to convert it in the contour length (in base pairs) of the longest loops.

Data analysis. To compare experimental kinetic plots the $p$-value was calculated using a statistical permutation test $[24,25]$.

Kinetic plots (the relative amount of DNA in the tail $F$ versus electrophoresis time $t$ ) were fitted according to two models. The first one, which can be called "one-step", corresponds to the standard equation of monomolecular kinetics:

$$
F=F m(1-\exp (-k t))
$$

where $F_{\mathrm{m}}$ is the maximum relative amount of DNA that can exit, $k$ is the rate constant. The second, "two-step" model takes into account a two-step behavior of the kinetic plots [17]. According to this model, the plots were fitted with the equation:

$$
F=A_{1}\left(1-\exp \left(-k_{1} t\right)\right)+\frac{A_{2}}{1+\exp \left(k_{2}\left(t_{0}-t\right)\right)},
$$

where $A_{1}$ and $A_{2}$ are the maximum amplitudes of the two components $\left(A_{1}+A_{2}=F_{\mathrm{m}}\right), k_{1}$ and $k_{2}$ are the rate constants, and $t_{0}$ is the transition half-time. The first term in Eq. 2 describes the first rapid phase of the DNA exit; the second term, which obeys the sigmoidal Boltzmann equation, corresponds to the second retarded phase.

The dependences of the relative amount of DNA in the tail $F$ on the contour length $L_{\mathrm{m}}$ of the longest loops in the tail were fitted with the equation derived in [20]:

$$
F=F_{m}\left[1-\left(1+\gamma L_{m}\right) \exp \left(-\gamma L_{m}\right)\right],
$$

where $\gamma$ is the linear loop density (the number of loops per $1 \mathrm{~kb}$ ).

\section{Results and Discussion}

As it was mentioned in the Introduction, the T98G cells can be arrested at G1 phase of the cell cycle. The first part of our experiments was done with these G1-arrested cells. Fig. 1A,B shows the kinetics of the comet tail formation during the comet assay. In comparison with human lymphocytes, for which the relative amount of DNA in the tails reached $21 \%$ after a long-time electrophoresis [17-20], for [the] T98G cells the saturation level of DNA in the tails is much lower. It may be suspected that a lower DNA exit might be related to the less effective lysis of these cells. However, the same maximum amount of DNA exit into the tail was observed for the nuclei isolated from the T98G cells (Fig. 1A, B). Hence, the lysis procedure was quite effective.

As it was shown in our previous works for human lymphocytes at different cell cycle phases [17, 20], the kinetic plots of DNA exit always have a two-step shape. The analysis of our previous results allowed us to conclude that the first step may be attributed to DNA on the nucleoid surface whereas the second 
step - to inner supercoiled loops, the exit of which is retarded and cooperative [17]. In the case of the T98G cells the two-step shape does not seem so obvious. In principle, the plot can be approximated by two models described in the Materials and Methods: the "one-step" model that obeys the standard equation (Eq. 1) of monomolecular kinetics (Fig. 1A, C); and the "two-step" model (Eq. 2) that includes the second cooperative step described by the sig- moidal Boltzmann equation (Fig. 1B, D). However, the comparison of residuals and $\chi^{2}$ values (Fig. 1C, D) clearly shows that the twostep model fits the experimental data much better.

An additional evidence of the two-step behavior was obtained in the experiments with chloroquine. As it was shown in our previous works [15-17], the migration rate of the inner loops is very sensitive to supercoiling: the

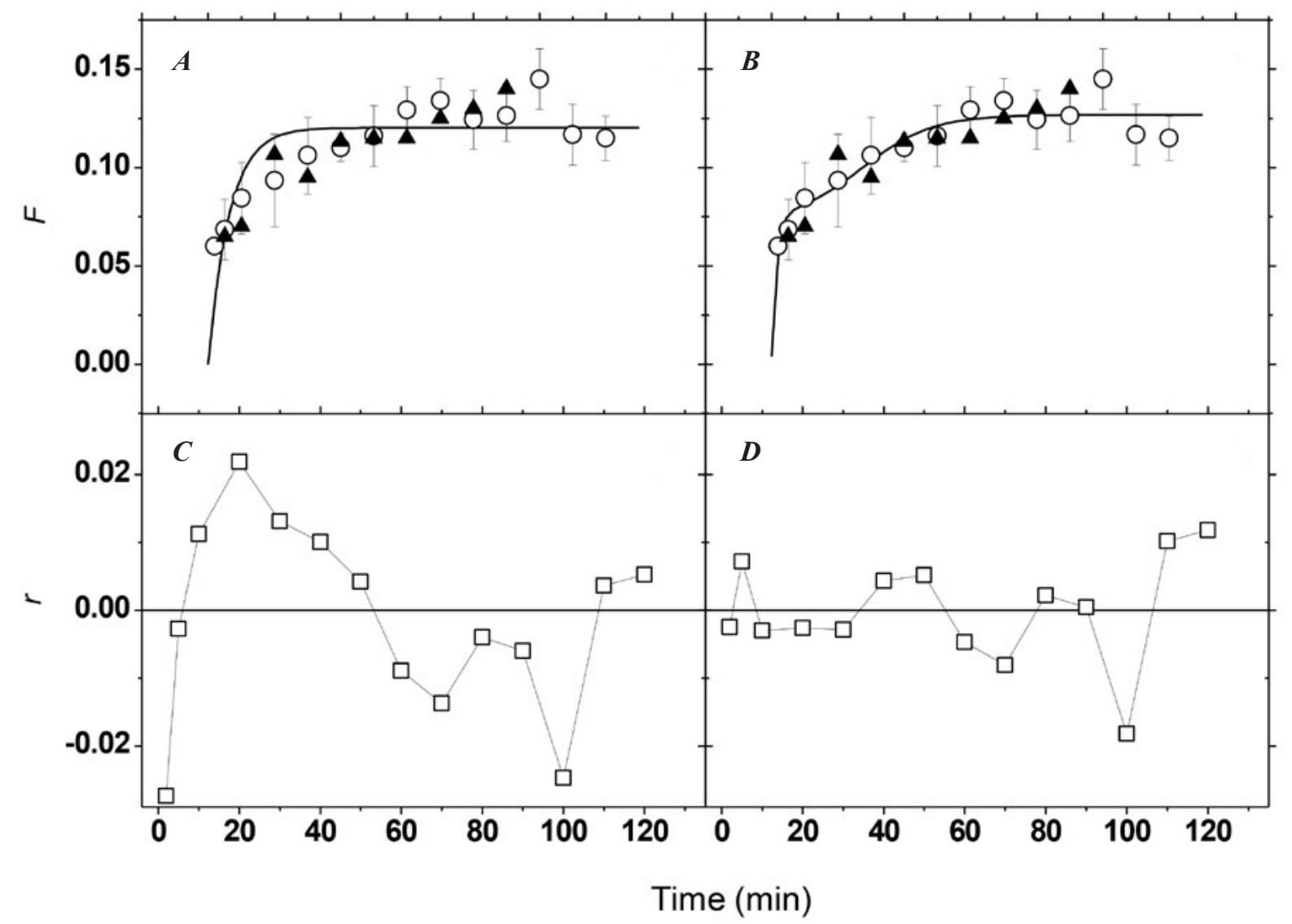

Fig. 1. The average relative amount $(F)$ of DNA in the comet tails as a function of electrophoresis time $(\mathrm{A}, \mathrm{B})$ and residuals $(r)$ between experimental points and theoretical curves $(C, D)$ for nucleoids obtained from T98G cells arrested at G1 phase. Data for nucleoids from isolated cell nuclei $(\boldsymbol{\Delta})$ are also presented in panels A and B. The theoretical curves are the results of fitting according to Eq. 1 (A, C) and Eq. 2 (B, D). The $\chi^{2}$ values for experimental points relative to theoretical curves are $2 \cdot 10^{-3}(\mathrm{~A}, \mathrm{C})$ and $8 \cdot 10^{-5}(\mathrm{~B}, \mathrm{D})$. 
migration is accelerated when the loops are relaxed due to partial DNA unwinding upon intercalation of chloroquine at the concentration $\sim 25 \mu \mathrm{g} / \mathrm{ml}$. In total agreement with those observations, the second step of the DNA exit from T98G-derived nucleoids was also accelerated at the same chloroquine concentration (Fig. 2).

Thus, similarly to the lymphocyte-derived nucleoids, the comet tail of the T98G-derived nucleoids is formed by two types of the loops: surface loops that migrate rapidly and inner supercoiled loops, the migration of which is retarded. However, while the amplitude of the first step of migration ( $A_{1}$ in Eq. 2$)$ is the same for both cell types $\left(A_{1}=0.07 \pm 0.01\right)$, the amplitude of the second step is very low for the T98G cells $\left(A_{2}=0.05 \pm 0.01\right.$ against $0.14 \pm 0.01$ for lymphocytes [17]). In other words, an essential decrease in the relative DNA amount in the tails in T98G-derived nucleoids is due

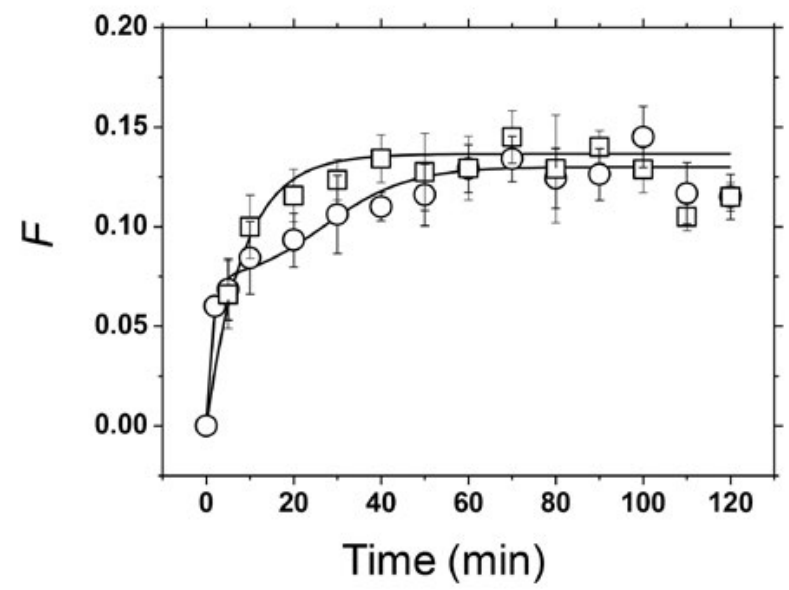

Fig. 2. The average relative amount $(F)$ of DNA in the comet tails as a function of electrophoresis time for nucleoids obtained from T98G cells arrested at G1 phase in the absence $(\circ)$ and in the presence chloroquine at the concentration of $25 \mu \mathrm{g} / \mathrm{ml}(\square) . p=0.019$ (permutation test). to the decreased number of the inner loops that can be resolved by the comet assay.

As it was noted above, the T98G cells considered so far were arrested at G1 phase. These cells can be reactivated: proliferation of these cells is renewed after addition of serum in the medium [22]. Such reactivation should obviously be accompanied by an increase in the transcriptional activity. To examine possible changes in the DNA loop organization upon the reactivation we have investigated the kinetics of DNA exit from nucleoids, derived from the reactivated cells (Fig. 3). In comparison with the G1-arrested cells, there were the following differences. First, an increase in the DNA amount in the tails was observed at both steps of the migration $\left(A_{1}=0.09 \pm 0.01\right.$, $\left.A_{2}=0.08 \pm 0.02\right)$. Second, an additional retardation was observed for the second step: the transition half-time (see Eq. 2) $t_{0}=41 \pm 10$ min against $27 \pm 8$ min for [the] nucleoids

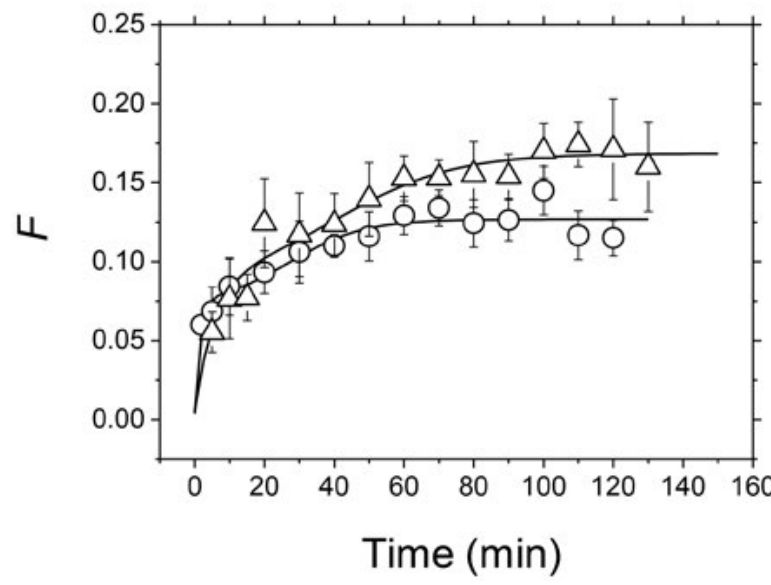

Fig. 3. The average relative amount $(F)$ of DNA in the comet tails as a function of electrophoresis time for nucleoids obtained from arrested at G1 phase $(\mathrm{O})$ and reactivated $(\Delta)$ T98G cells. $p=0.003$ (permutation test). 
derived from the G1-arrested cells. Thus, the reactivation of the $\mathrm{T} 98 \mathrm{G}$ cells was accompanied by an increase of DNA contained in both the surface and inner loops that can be resolved by the comet assay.

We have analyzed also the kinetics of the tail length during the comet assay, the parameter that gives an estimation of the contour length of the longest loops in the tail. Fig. 4 shows that the size of the longest loops was essentially higher for the reactivated T98G cells, especially for a long duration of electrophoresis. Such increase in the size may be a reason for both the increase in the DNA amount in the tails and the retardation of the DNA exit.

The correlations between the length of the longest loops and the relative amount of DNA in the tail for G1-arrested and reactivated cells are presented in Fig. 5. These dependences, which are proportional to the cumulative probabilities of the loops below some size to be present in the tail [20], allow one to estimate the loop density ( $\gamma$ in Eq. 3), the main parameter of the exponential distribution of the loop length [20]. Fitting Eq. 3 to dependences of Fig. 5 gives $\gamma=0.059 \pm 0.007 \mathrm{~kb}^{-1}$ for the G1-arrested cells and $\gamma=0.025 \pm 0.002 \mathrm{~kb}^{-1}$ for the reactivated T98G cells. Note that the loop density estimated is related only to the loops, the sizes of which are within the resolution of the comet assay (not larger than $\sim 300 \mathrm{~kb}$ ). A decrease in the density of these loops upon reactivation clearly occurs in favor of the larger loops that cannot be resolved by the comet assay. The same effect (a decrease of the loop density) was observed earlier for

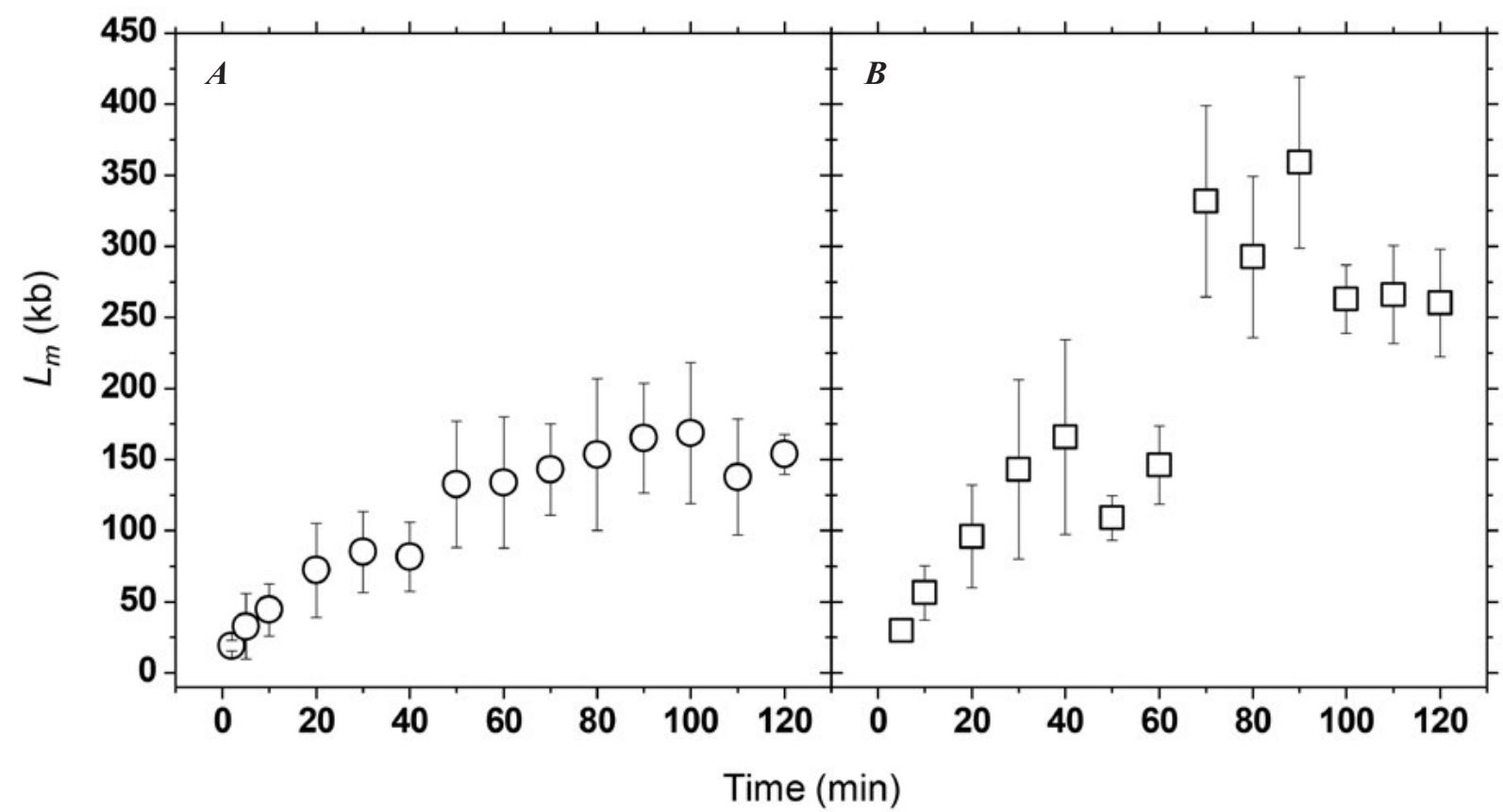

Fig. 4. The contour length of the longest loops in the tails $\left(L_{\mathrm{m}}\right)$ as a function of electrophoresis time for nucleoids obtained from arrested at G1 phase (A) and reactivated (B) T98G cells. 


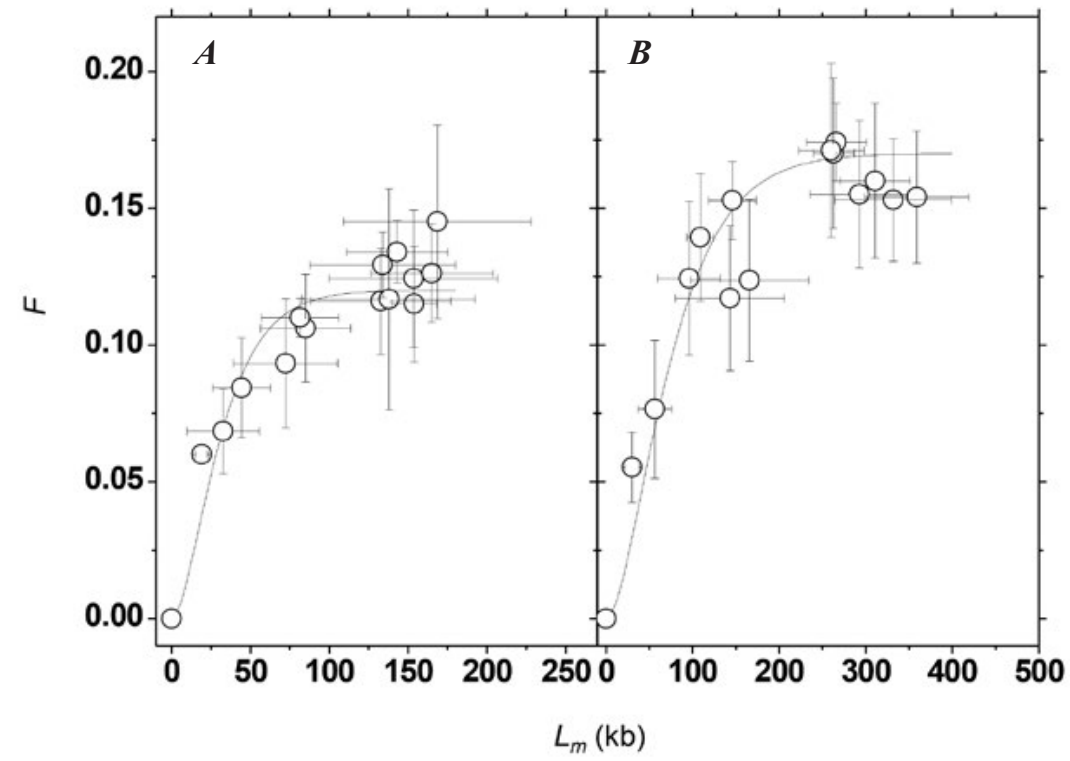

Fig. 5. Correlation between the average relative amount $F$ of DNA in the comet tails and the average contour length of the longest loops in the tail $L_{\mathrm{m}}$ for nucleoids obtained from arrested at G1 phase (A) and reactivated (B) T98G cells. the lymphocytes activated by interleukin 2 [20]. In other words, an increase in the loop size (which is in parallel with an increase of the largest loops within the resolution of the comet assay, Fig. 4) seems to be a general feature of activated cells.

\section{Conclusions}

The results of our analysis of the kinetics of electrophoretic track formation for the nucleoids derived from glioblastoma T98G cells can be summarized as follows. (1) The cells arrested at G1 phase of the cell cycle are characterized by a relatively low amount of DNA in the tails after a long-time comet assay. The main reason of this is a low content of DNA in the loops, the sizes of which are within the resolution of the comet assay (up to $\sim 300 \mathrm{~kb}$ ). (2) The reactivation of the T98G cells is accompanied by a redistribution of the loops: the contour length of the loops resolved by the comet assay essentially increases, in parallel with a decrease in the linear density of these loops along the genome. The results of this work, together with our results obtained earlier for activated lymphocytes, suggest that an increase in the loop size may be a general feature of the activated cells.

\section{REFERENCES}

1. Dekker J, Marti-Renom MA, Mirny LA. Exploring the three-dimensional organization of genomes: interpreting chromatin interaction data. Nat Rev Genet. 2013;14(6):390-403.

2. Gibcus JH, Dekker J. The hierarchy of the 3D genome. Mol Cell. 2013;49(5):773-82.

3. Dekker J, Mirny L. The 3D Genome as Moderator of Chromosomal Communication. Cell. 2016;164(6):1110-1121.

4. Dixon JR, Gorkin DU, Ren B. Chromatin Domains: The Unit of Chromosome Organization. Mol Cell. 2016;62(5):668-80. Review.

5. Ulianov $S V$, Shevelyov $Y Y$, Razin $S V$. Lamina-associated chromatin in the context of the mammalian genome folding. Biopolym. Cell. 2016; 32:327-333. 
6. Kadauke S, Blobel GA. Chromatin loops in gene regulation. Biochim Biophys Acta. 2009;1789(1):17-25.

7. Sexton T, Cavalli $G$. The role of chromosome domains in shaping the functional genome. Cell. 2015;160(6):1049-59.

8. Lieberman-Aiden E, van Berkum NL, Williams $L$, Imakaev M, Ragoczy T, Telling A, Amit I, Lajoie BR, Sabo PJ, Dorschner MO, Sandstrom R, Bernstein $B$, Bender MA, Groudine M, Gnirke A, Stamatoyannopoulos J, Mirny LA, Lander ES, Dekker J. Comprehensive mapping of long-range interactions reveals folding principles of the human genome. Science. 2009;326(5950):289-93.

9. Rao SS, Huntley MH, Durand NC, Stamenova EK, Bochkov ID, Robinson JT, Sanborn AL, Machol I, Omer AD, Lander ES, Aiden EL. A 3D map of the human genome at kilobase resolution reveals principles of chromatin looping. Cell. 2014;159(7):166580. doi: 10.1016/j.cell.2014.11.021. Erratum in: Cell. 2015;162(3):687-8.

10. Sanborn AL, Rao SS, Huang SC, Durand NC, Huntley MH, Jewett AI, Bochkov ID, Chinnappan D, Cutkosky A, Li J, Geeting KP, Gnirke A, Melnikov A, McKenna D, Stamenova EK, Lander ES, Aiden EL. Chromatin extrusion explains key features of loop and domain formation in wild-type and engineered genomes. Proc Natl Acad Sci U S A. 2015;112(47):E645665. doi: 10.1073/pnas.1518552112.

11. Fudenberg G, Imakaev M, Lu C, Goloborodko A, Abdennur N, Mirny LA. Formation of Chromosomal Domains by Loop Extrusion. Cell Rep. 2016;15(9):2038-49. doi: 10.1016/j.celrep.2016.04.085.

12. Vian L, Pękowska A, Rao SSP, Kieffer-Kwon KR, Jung S, Baranello L, Huang SC, El Khattabi L, Dose M, Pruett N, Sanborn AL, Canela A, Maman Y, Oksanen A, Resch W, Li X, Lee B, Kovalchuk AL, Tang Z, Nelson S, Di Pierro M, Cheng RR, Machol I, St Hilaire BG, Durand NC, Shamim MS, Stamenova EK, Onuchic JN, Ruan Y, Nussenzweig A, Levens D, Aiden EL, Casellas $R$. The Energetics and Physiological Impact of Cohesin Extrusion. Cell. 2018;173(5):1165-1178.e20. doi: 10.1016/j.cell.2018.03.072. Erratum in: Cell. 2018;175(1):292-294.

13. Olive PL. The comet assay. An overview of techniques. Methods Mol Biol. 2002;203:179-94.
14. Collins AR. The comet assay for DNA damage and repair: principles, applications, and limitations. $\mathrm{Mol}$ Biotechnol. 2004;26(3):249-61.

15. Afanasieva K, Zazhytska M, Sivolob A. Kinetics of comet formation in single-cell gel electrophoresis: loops and fragments. Electrophoresis. 2010;31(3): 512-9.

16. Zazhytska MO, Afanasieva KS, Chopei MI, Vikhreva $M A$, Sivolob $A V$. Influence of chloroquine on kinetics of single-cell gel electrophoresis. Biopolym. Cell. 2012;28:292-297.

17. Afanasieva K, Chopei M, Zazhytska M, Vikhreva M, Sivolob $A$. DNA loop domain organization as revealed by single-cell gel electrophoresis. Biochim Biophys Acta. 2013;1833(12):3237-3244.

18. Afanasieva K, Chopei $M$, Sivolob A. Chromatin in fractal globule state: evidence from comet assay. Biopolym. Cell. 2015;31:97-103.

19. Afanasieva K, Chopei M, Sivolob A. Single nucleus versus single-cell gel electrophoresis: kinetics of DNA track formation. Electrophoresis. 2015;36(78):973-7.

20. Afanasieva K, Chopei M, Lozovik A, Semenova A, Lukash L, Sivolob A. DNA loop domain organization in nucleoids from cells of different types. Biochem Biophys Res Commun. 2017;483(1):142-146.

21. Afanasieva K, Sivolob A. Physical principles and new applications of comet assay. Biophys Chem. 2018;238:1-7.

22. Stein GH. T98G: an anchorage-independent human tumor cell line that exhibits stationary phase G1 arrest in vitro. J Cell Physiol. 1979;99(1):43-54.

23. Kiseleva LN, Kartashev AV, Vartanyan NL, Pinevich AA, Samoilovich MP. Characteristics of A172 and T98G cell lines. Tsitologiia. 2016;58(5):349-55. English, Russian.

24. Elso CM, Roberts LJ, Smyth GK, Thomson RJ, Baldwin TM, Foote SJ, Handman E. Leishmaniasis host response loci (lmr1-3) modify disease severity through a Th1/Th2-independent pathway. Genes Immun. 2004;5(2):93-100.

25. Phipson B, Smyth GK. Permutation P-values should never be zero: calculating exact P-values when permutations are randomly drawn. Stat Appl Genet Mol Biol. 2010;9:Article39. 


\section{Організація петельних доменів ДНК в гліобластомних клітинах T98G за їх різних функціональних станів}

К. С. Афанасьєва, А. Ю. Семенова, Л. Л. Лукаш, А. В. Сиволоб

Резюме. Організація петельних доменів хроматину, яка відіграє важливу роль у регуляції транскрипції, напевно може залежати від функціонального стану клітини. Мета роботи полягала у дослідженні можливої реорганізації петель ДНК при функціональних переходах у гліобластомних клітинах T98G. Методи. Ми застосовували метод електрофорезу ДНК ізольованих клітин (кометний електрофорез) для аналізу кінетики міграції петель ДНК з нуклеоїдів, отриманих з лізованих клітин. Результати. Клітини, заарештовані на фазі G1 клітинного циклу, характеризуються порівняно низьким вмістом ДНК у хвостах комет внаслідок низького вмісту ДНК у складі петель, що знаходяться у межах роздільної здатності кометного електрофорезу (до 300 кб). Після реактивації клітин контурна довжина петель суттєво зростає, паралельно зі зниженням лінійної щільності петель уздовж геному. Висновки. Оскільки подібні ефекти спостерігались нами раніше для активованих лімфоцитів, ми робимо висновок, що зростання розміру петель та відповідне зниження їхньої лінійної щільності може бути загальною характеристикою активованих клітин.

Кл юч о в і с л о в а: петлі ДНК, клітинна лінія T98G, кометний електрофорез, функціональні стани клітин.

\section{Организация петельных доменов ДНК в глиобластомных клетках T98G при их разных функциональных состояниях}

К. С. Афанасьева, А. Ю. Семенова, Л. Л. Лукаш, А. В. Сиволоб

Резюме. Организация петельных доменов хроматина, играющая важную роль в регуляции транскрипции, предположительно может зависеть от функционального состояния клетки. Цель работы заключалась в исследовании возможной реорганизации петель ДНК при функциональных переходах в глиобластомных клетках T98G. Методы. Мы использовали электрофорез ДНК изолированных клеток (кометный электрофорез) для анализа кинетики миграции петель ДНК из нуклеоидов, полученных из лизированных клеток. Результаты. Клетки, арестованные на фазе G1 клеточного цикла, характеризуются сравнительно низким содержанием ДНК в хвостах комет из-за низкого содержания ДНК в составе петель, которые находятся в пределах разрешающей способности кометного электрофореза (до >300 кб). После реактивации клеток контурная длина петель существенно возрастает, параллельно со снижением линейной плотности петель вдоль генома. Bblвodb. Поскольку аналогичные эффекты наблюдались нами ранее для активированных лимфоцитов, мы заключили, что возрастание размера петель и соответствующее снижение их линейной плотности может быть общей характеристикой активированных клеток.

К л юч е в ы е с л о в а: петли ДНК, клеточная линия T98G, кометный электрофорез, функциональные состояния клеток.

Received 10.10.2018 